\title{
Lake Alaotra wetlands: how long can Madagascar's most important rice and fish production region withstand the anthropogenic pressure?
}

Pina L. Lammers', ", Torsten Richter', Patrick O. Waeberll, III, Jasmin Mantilla-Contreras!

\begin{abstract}
The Alaotra wetlands represent the biggest lake and wetland complex in Madagascar and are home of several endemic species. The region constitutes the largest rice production area and inland fishery of Madagascar. Rice and fish are the main local sources of income. While the population has increased fivefold during the last 40 years, the growing need for resources is continuously increasing the pressure on the wetland system. In this study, vegetation and water parameters were collected within three sites differing by level of degradation in order to evaluate the current ecological state of the wetland. The results show that high levels of ongoing anthropogenic disturbance are favoring the formation of a new plant community in the fringe area of the marsh belt. This area is now dominated by invasive species such as the water hyacinth (Eichhornia crassipes) which shows a mean coverage up to $53 \%$ and water ferns (Salvinia spp.) with a mean coverage up to $31.4 \%$. Lake water levels were very low and decreased during the dry season to a mean level of only $3 \mathrm{~cm}$ in the littoral zone. Signs of eutrophication like hypoxia (mean saturation of only $22 \%$ ), increased phosphate concentrations (1.18 $\mathrm{mg} \mathrm{L}^{-1}$ ) and black colored, foul smelling water were observed. Under a likely scenario of growing anthropogenic pressures, it remains unclear what the current trends will bring for the wetland's future.
\end{abstract}

\section{RÉSUMÉ}

La zone humide de l'Alaotra représente le plus grand lac et complexe de zones humides de Madagascar hébergeant plusieurs espèces endémiques. La région constitue la première production de riz et de pêche dulcicole de l'île. Le riz et les ressources piscicoles sont les principales sources de revenus locaux. L'effectif de la population humaine locale a été quintuplé au cours des dernières 40 années et les besoins en ressources ont augmenté en conséquence de sorte que les pressions sur la zone humide ont été exacerbées. Dans cette étude, des paramètres portant sur la végétation et l'eau du lac ont été collectés dans trois sites qui dif-

\author{
Correspondence: \\ Pina L. Lammers \\ Ecology and Environmental Education Group, Institute of Biology \\ and Chemistry, Hildesheim, Germany \\ E-mail: pina.lammers@gmail.com
}

fèrent par le niveau de dégradation pour évaluer l'état écologique actuel de la zone humide. Les résultats montrent que le niveau élevé des perturbations anthropiques favorise la formation d'une nouvelle communauté végétale sur la ceinture du marais. Cette zone est dominée par des espèces de plantes envahissantes à l'exemple de la jacinthe d'eau (Eichhornia crassipes) dont la couverture moyenne est de $53 \%$ et de la fougère d'eau (Salvinia spp.) avec une couverture moyenne de $31,4 \%$. Les niveaux du lac sont bas et diminuent jusqu'à $3 \mathrm{~cm}$ de moyenne dans la zone littorale pendant la saison sèche. Des signes d'eutrophisation comme I'hypoxie (saturation moyenne de 22\%), I'augmentation de la concentration de phosphate $\left(1,18 \mathrm{mg} \mathrm{L}^{-1}\right)$ et la présence d'eau de couleur noire et nauséabonde ont été observés. Dans un possible scénario avec une augmentation des pressions humaines, les tendances actuelles restent difficiles à comprendre pour l'avenir de la zone humide.

\section{INTRODUCTION}

Wetlands are diverse ecosystems, including both fresh water and marine habitats (sensu Van der Valk 2012). They build the transition zone between land and water and fulfill various ecological functions such as nutrient and groundwater retention and supply, flood control and flow regulation, sediment retention, erosion and salinity control, water purification and climate stabilization. Wetlands further provide crucial ecosystem services to humans such as water, fish, natural products (e.g., construction material, crafts and medicinal plants) and resources for agriculture, cattle farming and energy production, game, wood and services like facilitation of transport and recreation (Dugan 1990, Roggeri 1995, Mitsch and Gosselink 2000, Turner et al. 2000, Junk 2002).

The Alaotra wetlands, situated on the northeastern part of the Madagascar highlands, are formed by the Lake Alaotra (less than 20,000 hectares of open water body), and by 23,000 ha of fresh water marshes (Bakoariniaina et al. 2006, Copsey et al. 2009a). The surrounding 120,000 ha of rice fields constitute Mada- 


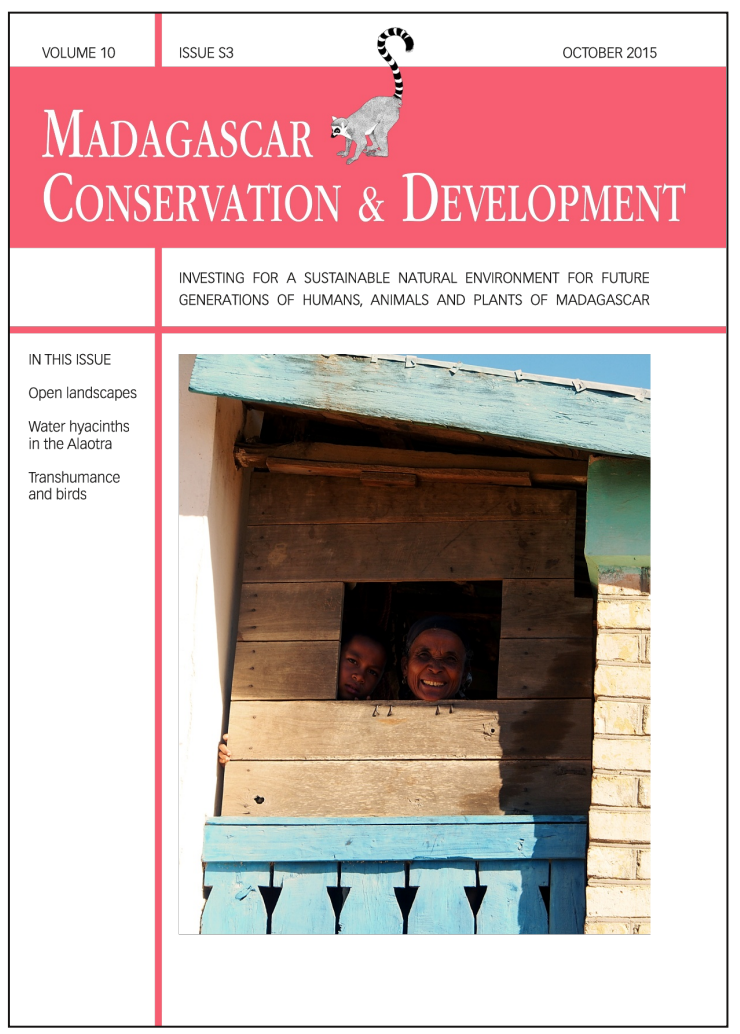

Madagascar Conservation \& Development is the journal of Indian Ocean e-Ink. It is produced under the responsibility of this institution. The views expressed in contributions to MCD are solely those of the authors and not those of the journal editors or the publisher.

All the Issues and articles are freely available at http://www.journalmcd.com

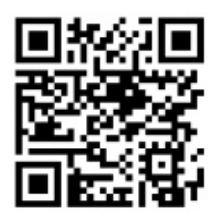

Contact Journal MCD

info@journalmcd.net for general inquiries regarding MCD funding@journalmcd.net to support the journal

Madagascar Conservation \& Development Institute and Museum of Anthropology

University of Zurich

Winterthurerstrasse 190

$\mathrm{CH}-8057$ Zurich

Switzerland

Indian Ocean e-Ink

Promoting African Publishing and Education

www.ioeink.com

Missouri Botanical Garden (MBG)

Madagascar Research and Conservation Program

BP 3391

Antananarivo, 101, Madagascar 
gascar's biggest rice production area with an annual yield of ca. 300,000 tons (Plan Régional de Développement 2005). In addition, Lake Alaotra supplies the country with 2,500 tons of freshwater fish annually (ibid).

The wetland complex provides habitat for a variety of plant and animal species. At least three vertebrate taxa are microendemics: the Alaotra gentle lemur (Hapalemur alaotrensis) is Critically Endangered with an estimated population of less than 2,500 individuals in 2005 (Ralainasolo et al. 2006, Ratsimbazafy et al. 2013), the Madagascar rainbowfish Rheocles alaotrensis (Bedotiidae) (Reinthal and Stiassny 1991) and a recently described small carnivore Salanoia durrelli (Eupleridae) (Durbin et al. 2010).

Although declared as a Ramsar site of international importance in 2003 and 'Nouvelle Aire Protégée' since 2007, the wetland system experiences continuous anthropogenic pressures and degradation (Peck 2004). During the last 50 years, the human population in the two lake districts has increased fivefold from some 110,000 inhabitants in 1960 (Pidgeon 1996) to over 560,000 inhabitants (INSTAT 2013) leading to a steadily increasing demand for natural resources and agricultural land. While the fresh water marshes are shrinking due to burning and conversion into rice fields, the lake suffers from massive overfishing. Further problems include the invasion of non-native fish and plant species. Among invasive plant species, the water hyacinth (Eichhornia crassipes) is one of the most problematic while it causes several ecological, social and economic problems; water loss due to increased evapotranspiration, oxygen loss, decreased phytoplankton productivity (associated with changes in the food web) due to decreasing light conditions, loss of biodiversity and clogging of waterways (Masifwa et al. 2001, Rommens et al. 2003, Mangas-Ramirez and Elias-Gutierrez 2004, Andrianandrasana et al. 2005, Villamagna and Murphy 2010).

Water loss and the decreasing open water surface represent serious problems in the area since Lake Alaotra is a shallow lake with a maximum depth of four meters. Sedimentation, transformation of water and streams for agricultural irrigation and environmental degradation have already reduced the lake to $20-30 \%$ of its original size (Bakoariniaina et al. 2006, Kusky et al. 2010). Shallowness and tropicality imply that physical aspects of water depth and water temperature are the determining features in the environmental regulation of the lake system (Talling 2001). Shallow lakes show a higher sensitivity towards rapid changes in those two parameters. While wetlands in tropical Africa seem to be well documented (e.g., Lake Chilwa (two meters depth, HowardWilliams 1975), Lake Chad (four meters depth, El-Shabrawy and AlGhanim 2012), Lake George (2.4 m depth, Ganf 1974), Lake Naivasha (four meters depth, Gaudet 1977), Lake Nakuru (four meters depth, Vareschi 1982), there is a lack of research on freshwater lakes in Madagascar. For Lake Alaotra, studies have mainly focused on population biology, distribution and behavior of vertebrate species, especially on Hapalemur alaotrensis, as well as on bird and fish species (Wilmé 1994, Mutschler et al. 1998, Hawkins et al. 2000, Nievergelt et al. 2002, Waeber and Hemelrijk 2003, Ralainasolo 2004, Ralainasolo et al. 2006, René de Roland et al. 2009, Guillera-Arroita et al. 2010). There are few studies only including ecological data and interactions, e.g., studies focusing on different trophic levels and on the consequences of environmental changes on habitat quality and biodiversity. The last comprehensive study about the ecological state of the lake dates back to some 20 years (Pidgeon 1996). The marsh vegetation is important in terms of habitat and food source for terrestrial and aquatic communities. Changes in vegetation heterogeneity and composition are therefore important attributes to assess ecosystem functioning. Physico-chemical features of the water (e.g., water level and temperature, dissolved oxygen, $\mathrm{pH}$, luminosity, conductivity and nutrient content) are determining ecological parameters for aquatic communities (Lévêque 1997, Prepas and Charette 2003, Ekau et al. 2010). However, the terrestrial system relies on the aquatic system as well. This article will present an update of the lake's water quality and vegetation parameters in order to draw some general conclusions on the current wetland conditions.

\section{METHODOLOGY}

STUDY AREA. The study was conducted at Lake Alaotra $\left(E 048^{\circ} 26^{\prime}, S 17^{\circ} 31^{\prime}\right)$, Madagascar (Figure 1). The lake is situated $750 \mathrm{~m}$ above sea level and lies in a tectonic basin encompassing an area of 685,500 ha (Andrianandrasana et al. 2005, Ferry et al. 2009, Kusky et al. 2010). The lake is shallow with water depths of 1.5 to $2 \mathrm{~m}$ on average and a maximum of $4 \mathrm{~m}$ during the rainy season (Pidgeon 1996). The lake obtains water from infiltration, runoff and flooding (Ramsar 2007). Four main rivers feed the Lake Alaotra: the Anony and the Sahamaloto in the north and the Sasomangana and the Sahabe in the south. The Maningory in the northeast constitutes its effluent (Chaperon et al. 1993). The Alaotra region is characterized by a tropical climate. Mean annual temperature is $20.6{ }^{\circ} \mathrm{C}$, but ranges from $11.1^{\circ} \mathrm{C}$ in July to $28.4{ }^{\circ} \mathrm{C}$ in January (Ferry et al. 2009). The basin is characterized by an annual precipitation of 900 to $1,250 \mathrm{~mm}$ with a maximum of $250 \mathrm{~mm}$ in January during the warm rainy season (November-March).

The freshwater marshes of Lake Alaotra are dominated by sedges and grasses. The higher strata is presented by common reed (Phragmites australis), cyperus (Cyperus madagascariensis) and the Convolvulaceae, Argyreia vahibora, while the lower strata is settled by Cyperus latifolius, Leersia hexandra, the fern Cyclosorus interruptus, Persicaria glabra and Echinochloa pyramidalis (Mutschler and Feistner 1995, Pidgeon 1996, Ranarijaona 2007). At least three invasive species have colonized successfully the shallow areas of the lake: the invasive Eichhornia crassipes, and the water ferns Salvinia molesta and Azolla spp. (Andrianandrasana et al. 2005).

STUDY SITES. Three different sites were chosen for this study in terms of location at the lake, human population density
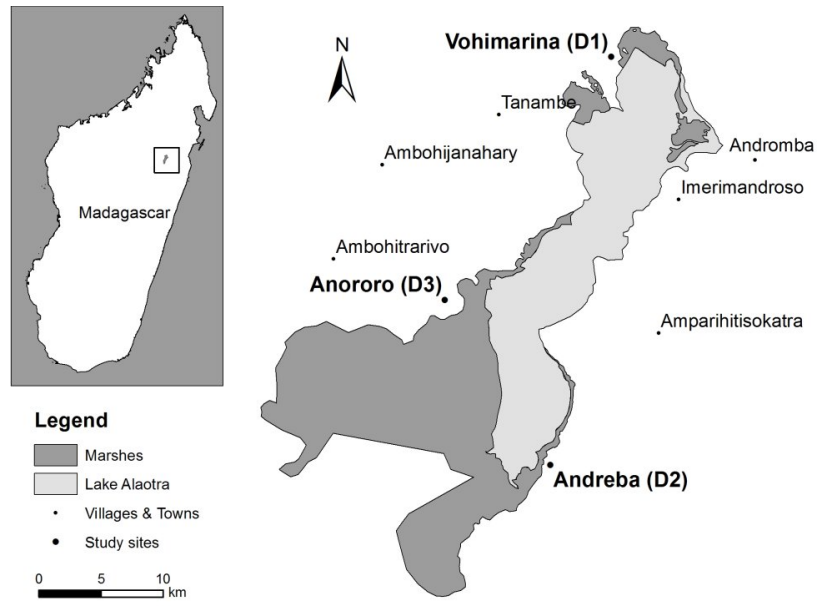

Figure 1. Location of the Alaotra wetlands and the study sites Vohimarina (D1), Andreba (D2) and Anororo (D3). (Modified from Durrell 2012) 
and level of degradation: Andreba, Anororo and Vohimarina ( $F i$ gure 1). The level of degradation was defined a priori by (i) protection status and existence of local management units for the marshes, (ii) abundance of the invasive Eichhornia crassipes, (iii) intensity of fishery activities, (iv) presence of sanitation and (V) water level. Evaluation of the criteria was based on information from the fokontany (smallest administrative unit in Madagascar) and direct observations. Vohimarina, on the northern side of Lake Alaotra (E048 $32^{\prime} 59.7^{\prime \prime}, 517^{\circ} 20^{\prime} 02.4^{\prime \prime}, 761 \mathrm{~m}$ a.s.l.) has a population of less than 500 inhabitants and encompasses 300 ha of marshes (Andrianandrasana et al. 2005); its marshes are defined as low-degraded (D1). It is described by a low water level, a village with low fishery activities and a low E. crassipes occurrence as well as the presence of sanitation and a community-based association (VOI, Vondron' Olona Ifototra) for the management of the marshes. Andreba, on the east side of the lake (E048 $30^{\prime}$ 08.0', S17 37' 51.7", 739 m a.s.l.) has 4,800 inhabitants and 235 ha of marshes (Andrianandrasana et al. 2005). Its marshes are intermediate-degraded (D2). Like Vohimarina, Andreba has a sanitation and a VOI but differs in terms of increased fishery activities and higher abundance of E. crassipes. Anororo, on the west side of the lake (E048 $26^{\prime}$ 01.4', S17 $30^{\prime} 44.0^{\prime \prime}, 724$ m a.s.l.) has a population of 8,000 inhabitants (Copsey et al. 2009b) and entails 9,850 ha of marshes (ibid). Water levels are higher than in the other sites. Its marshes are considered as highly-degraded (D3) because of a high occurrence of E. crassipes combined with high fishery activities, no sanitation and the absence of the VOI in 2012/13.

DATA SAMPLING. Environmental parameters were assessed in the marsh vegetation and open water of the lake across all three sites from November 2012 to April 2013. For each study site, 9 line transects (each of $220 \mathrm{~m}$ length and $1 \mathrm{~m}$ width) were established along the lake shore (Figure 2a, b). At all three locations, a canal represents the main connection between the village and the lake. Through the canal, municipal and agricultural wastewater is discharged directly into the lake. Further, the canal and its surroundings are subjected to mechanical disturbance by frequent boat traffic, fishery and cultivation activities. To detect habitat changes along a nutrient and mechanical disturbance gradient, four transects were placed on both sides of the canal and one transect was located near the canal $(10 \mathrm{~m})$. The ecological state of Lake Alaotra was assessed by sampling vegetation and water parameters. Vegetation parameters were assessed in all transects, whereas the water parameters were determined in the core-transects only (Figure 2a, b).

WATER PARAMETERS. The water depth $(\mathrm{cm})$ was determined using a measuring rod. Water quality was assessed by measurements of conductivity ( $\left.\mu \mathrm{S} \mathrm{cm}^{-1}\right), \mathrm{pH}$, temperature $\left({ }^{\circ} \mathrm{C}\right)$ and dissolved oxygen (mg L-1 and \%). All water quality measurements were performed with a digital multi-meter (WTW, Multi 350i). Luminosity (IUX) was recorded with a digital lux-meter (PHYWE, model: 07137-00). Water quality and depth were sampled along the four core-transects. Daily physicochemical fluctuations were accounted by sampling the water parameters during four periods: 0700-1000h, 1000-1300h, 1300-1600h and 1600-1900h. The temporarily low water levels of the lake during the dry season made it difficult to reach the plots by boat and thus measurements were restricted to $n=20$ per day. To detect seasonal changes, data were collected during the period of lowest lake water levels at the on

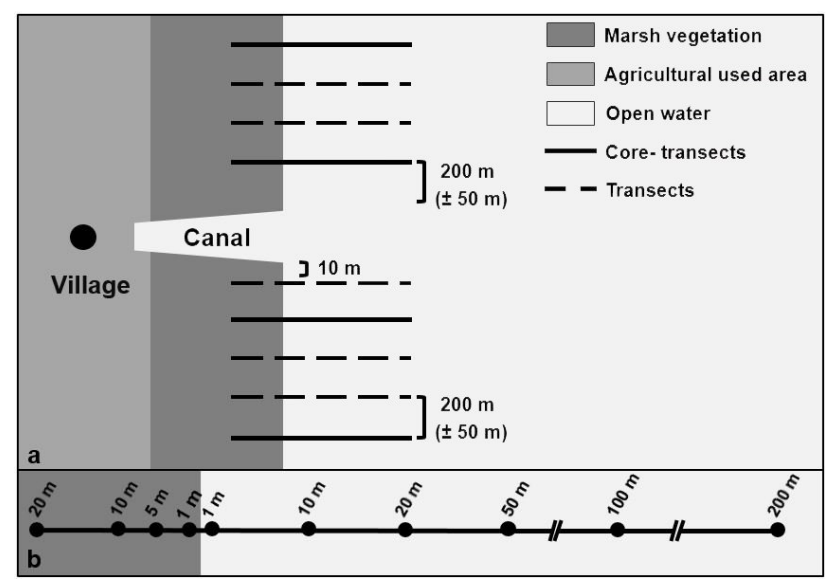

Figure 2. Direction and location of transects and plots in the littoral zone of Lake Alaotra. (a) Four transects were set out on each sides of the canal. One transect was additionally installed near the canal (10 $\mathrm{m}$ distance). (b) In each transect, a total of ten $1 \mathrm{~m}^{2}$-plots were installed, four in the lake shore vegetation - 20, 10, 5 and $1 \mathrm{~m}$ from the water edge - and six plots in the open water - 1, 10, 20, 50, 100 and $200 \mathrm{~m}$ from the lake shore vegetation. (The geographical coordinates of all plots were determined using a UTM, WGS 84 GPS)

set of the rainy season in 2012 (December 2012-January 2013; it only started raining in February; for brevity, it will be termed 'dry season' for the remainder of this manuscript) and during March-April 2013; this will be termed 'rainy season'. Sampling during the dry season was performed in surface water $(0-10 \mathrm{~cm}$ depth) of the open water plots (10-200 m); due to higher water levels in the rainy season, analyzes were additionally done in plots within vegetation $(20$ and $10 \mathrm{~m})$ and within deep water $(1.5 \mathrm{~m}$ depth). In total $n=240$ measurements were performed during the dry season versus $n=672$ measurements in the rainy season.

Nutrient concentrations were measured during midday in two core-transects per site using a photometer (WTW, Photoflex Turb). Samples to detect nitrite $\left(\mathrm{NO}_{2}{ }^{-}\right)$, nitrate $\left(\mathrm{NO}_{3}{ }^{-}\right)$and phosphate $\left(\mathrm{PO}_{4}{ }^{3-}\right)$ were taken in the surface water (0-10 $\mathrm{cm}$ depth). For these measurements, open water plots (10 $\mathrm{m}$ to $200 \mathrm{~m}$ ) during the dry season (December 2012-January 2013, $n=30$ ) and the rainy season (March-April 2013, $\mathrm{n}=30$ ) were sampled. Ammonia $\left(\mathrm{NH}_{4}^{+}\right)$ could not be measured due to the high air temperatures at the study sites and the missing option for cooling.

VEGETATION PARAMETERS. The lake shore vegetation was described using plant diversity, species abundance and composition as well as vegetation structure. Data were collected from February until March 2013 in all plots $(n=270)$. Plant species richness, total plant cover per plot and cover of each species were determined. Plant cover estimations were obtained in percentage for each plant species applying Londo's decimal scale (Londo 1976) and completed by open water and dead organic material cover estimates in percentage. Plant species were determined in the herbarium of the Parc Botanique et Zoologique de Tsimbazaza, Antananarivo, Madagascar. Vegetation structure was measured in all plots and was defined by vertical density of the vegetation, visually estimated as percentage in the plot ( $1 \mathrm{~m}$ section) for defined height intervals.

DATA ANALYSES. All statistical tests were done with the software SPSS for Windows (IBM, version 21). The comparison of data was performed with the nonparametric Mann-Whitney U-test for independent samples (two-tailed). Because of multiple comparisons $\alpha$ level ( $\alpha=0.05$ ) was lowered using the sequential Bonferroni correction (Bland and Altmann 1995, Abdi 2010). 
To detect site specific differences of plant species cover, plots without vegetation cover (100\% open water surface) were excluded resulting in a sample size of $n=175$. For the comparison of plant species abundance related to human disturbance, transects near the canal (200 m and $10 \mathrm{~m}$ ) were compared with the ones located in a greater distance $(400 \mathrm{~m}, 600 \mathrm{~m}, 800 \mathrm{~m})$. Water parameters were analyzed with respect to seasonal changes, site specific differences, differences between deep and surface water, vegetation and open water. Water parameters within vegetation plots were analyzed separately because only sampled during the rainy season. Nitrite, nitrate and phosphate contents of the water were analyzed in order to detect seasonal changes and differences between the low-, the intermediate- and the high-degraded site.

\section{RESULTS}

Conductivity: The concentration of dissolved material present in ionic form was generally low for all the study sites (Table 1). During the dry season, mean values ranged from $79 \mu \mathrm{S} \mathrm{cm-1}^{-1}$ in Vohimarina (D1) to $98 \mu \mathrm{S} \mathrm{cm}^{-1}$ in Andreba (D2). In contrast, during the rainy season mean values decreased significantly ( $p \leq 0.001$, $\mathrm{n}=160$ ) to a range between $50 \mu \mathrm{S} \mathrm{cm}^{-1}$ for Anororo (D3) and $81 \mu \mathrm{s} \mathrm{cm}{ }^{-1}$ for Vohimarina (D1).

$\mathrm{pH}$ : During the dry season, mean values of $\mathrm{pH}$ measured in the surface water ranged between 6.8 in Andreba (D2) to 7.0 in Anororo (D3). In the rainy season, the pH ranged from around 6.4 (D2 and D3) to 7.4 (D1) (Table 1). Minimum pH ranged between 5.6 and 6.1 in the dry season and 6.0 to 6.5 in the rainy season (Table 2).

Water level: The water level of Lake Alaotra was subjected to high seasonal fluctuations (Table 1). During the dry season, the water level in the littoral zone ranged from $14.6 \mathrm{~cm}$ (D3) to $11.7 \mathrm{~cm}$ (D1) and was extremely low in Andreba (D2) with a mean level of three centimeters (Figure $3 a, b)$. In the rainy season it raised up significantly ( $p \leq 0.001, n=160$ ) ranging between $182 \mathrm{~cm}$ in Andreba (D2) and $205 \mathrm{~cm}$ in Vohimarina (D1).

Table 1. Mean $(\overline{\mathrm{X}})$, standard deviation (SD) and range (Min., Max.) of the water parameters at the three study sites with different level of degradation. (Vohimarina, D1 = low, Andreba; D2 = intermediate, Anororo; D3 = high. Presented are data measured within the open water in the dry season (surface water) and the rainy season - surface water and deep water - determined during four periods a day: $7000-1000 \mathrm{~h}, 1000-1300 \mathrm{~h}, 1300-1600 \mathrm{~h}$ and 1600-1900h. Asterisks shown with the values of the dry season (surface water) indicate statistical significant differences between dry and rainy season $(n=160)$. Asterisks presented with the values of the rainy season (deep water) indicate statistical significant differences between surface and deep water $(n=160)$; significance level: $\left.p \leq 0.05={ }^{*}, p \leq 0.01={ }^{* *}, p \leq 0.001={ }^{* * *}\right)$

\begin{tabular}{|c|c|c|c|c|c|c|c|c|c|c|c|c|c|}
\hline & \multirow{2}{*}{ later parameters } & \multicolumn{4}{|c|}{ D1 $(n=80)$} & \multicolumn{4}{|c|}{ D2 $(n=80)$} & \multicolumn{4}{|c|}{ D3 $(n=80)$} \\
\hline & & $\bar{x}$ & SD & Min. & Max. & $\hat{\Lambda}$ & SD & Min. & Max. & $\bar{x}$ & SD & Min. & Max. \\
\hline \multirow{14}{*}{ 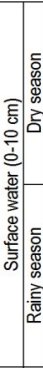 } & Conductivity $\left(\mu \mathrm{S} \mathrm{cm} \mathrm{cm}^{-1}\right)$ & $80^{* * *}$ & 12.1 & 65 & 131 & $98^{\star \star *}$ & 20 & 67 & 156 & $89^{*+* k}$ & 14.6 & 62 & 116 \\
\hline & $\mathrm{DO}\left(\mathrm{mg} \mathrm{L}^{-1}\right)$ & 5.0 & 1.6 & 0.1 & 7.4 & 3.7 & 1.9 & 0.1 & 7.7 & $6.3^{* * *}$ & 1.1 & 2.3 & 3.0 \\
\hline & DO $(\%$ & 70 & 21 & 1.2 & 99 & 52 & 28 & 1.6 & 135 & $92^{* * *}$ & 18.9 & 30 & 23 \\
\hline & $\mathrm{pH}$ & $9^{* * * x}$ & 0.2 & 5.6 & 7.3 & $6.8^{* * *}$ & 0.3 & 6.2 & y & $7.0^{* * *}$ & 3 & 1 & \\
\hline & Temp & $29.6^{\star \star *}$ & 3.0 & 21.9 & 36.4 & 30.8 & 4.4 & 21.3 & 41.3 & $29.8^{* * *}$ & 3.7 & 23.2 & 36.8 \\
\hline & Max. Wa & $7^{\star \star *}$ & 4.6 & 0.5 & 23 & $3.0^{* * *}$ & 2.3 & 1.0 & 10.0 & $14.6^{* * *}$ & 4.4 & 7.0 & 22 \\
\hline & Ligh & $19^{* *}$ & 699 & 46 & 2839 & $326^{\text {tom }}$ & 263 & 14.3 & 1272 & $1826^{\text {tant }}$ & 1407 & 23 & 6350 \\
\hline & Conductivity & 64 & 2.4 & 60 & 81 & 81 & 9.7 & 66 & 109 & 50 & 6.1 & 31 & 62 \\
\hline & DC & 5.3 & 0.7 & 3.9 & 6.6 & 3.4 & 2.1 & 0.2 & 7.5 & 3.1 & 1.5 & 0. & 8.0 \\
\hline & & 69 & 9.4 & 44 & 89 & 50 & 32 & 2.3 & 117 & & 22 & 6.7 & 110 \\
\hline & & 7.4 & 0.3 & 6.5 & 3 & 6.4 & 0.2 & 6.1 & 8 & & 0.3 & 6.0 & 7.0 \\
\hline & Temp & 25.7 & 0.9 & 24.0 & 29.1 & 29.6 & 2.7 & 26.0 & 35.3 & 25.7 & 1.3 & 23.5 & 29. \\
\hline & Max. Water & 205 & 6.9 & 195 & 220 & 182 & 9.2 & 170 & 205 & 195 & 4.9 & 85 & 200 \\
\hline & & 530 & 419 & 10.0 & 1779 & 149 & 143 & 0.0 & 525 & 1066 & 1422 & 0.0 & 6830 \\
\hline \multirow{7}{*}{ 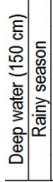 } & Conductivity & 64 & 1.3 & 58 & 69 & $95^{* \star \star}$ & 11.3 & 74 & 122 & 50 & 5.3 & 41 & \\
\hline & & 5.4 & 0.7 & 3.2 & 6.8 & $2.1^{*}$ & 0.4 & 1.2 & 3.1 & 3.1 & 0.9 & 1.7 & 5.0 \\
\hline & 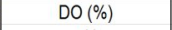 & 72 & 9.0 & 47 & 89 & $28^{* *}$ & 5.0 & 16.6 & 43 & 41 & 12.2 & 22 & 35 \\
\hline & 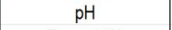 & 7.4 & 0.4 & 6.5 & 8.3 & $6.3^{* * *}$ & 0.1 & 6.1 & 6.6 & 0.4 & 0.2 & 6.0 & 7.0 \\
\hline & & $25.1^{\star \star \star}$ & 0.6 & 23.8 & 26.6 & $26.8^{\star \star *}$ & 0.7 & 25.8 & 28.2 & $25.0^{* *}$ & 0.7 & 22.4 & 26.8 \\
\hline & Max. Wat & 205 & 6.9 & 195 & 220 & 182 & 9.2 & 170 & 205 & 195 & 5.0 & 5 & 200 \\
\hline & Light (lux) & $0.0^{\star \star \star}$ & 0.0 & 0.0 & 0.0 & $3.8^{\star \star \star}$ & 16.4 & 0.0 & 99 & $0.0^{* \star *}$ & 0.0 & 0.0 & 0.0 \\
\hline
\end{tabular}

Table 2. Mean ( $\bar{x}$, standard deviation (SD) and range (Min., Max.) of nitrate, nitrite and phosphate at the three study sites with different level of degradation. (D1 = low, D2 = intermediate, D3 = high. Measurements in the dry season and in the rainy season are presented. Samples were taken during midday (1300h) in the surface water (depth $=0-10 \mathrm{~cm}$ ). Asterisks shown with the values of the dry season indicate statistical significant differences between dry and rainy season; significance level: $p \leq 0.05=*, p \leq 0.01=* *, p \leq 0.001=* * *)$

\begin{tabular}{|c|c|c|c|c|c|c|c|c|c|c|c|c|c|}
\hline & \multirow{2}{*}{ Water parameters } & \multicolumn{4}{|c|}{$D 1(n=10)$} & \multicolumn{4}{|c|}{$D 2(n=10)$} & \multicolumn{4}{|c|}{$D 3(n=10)$} \\
\hline & & $\bar{x}$ & $S D$ & Min. & Max. & $\bar{x}$ & SD & Min. & Max. & $\bar{x}$ & $S D$ & Min. & Max. \\
\hline \multirow{6}{*}{ 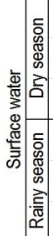 } & Nitrite (mg L-1) & $0.13^{* \star * x}$ & 0.02 & 0.11 & 0.16 & $0.04^{*}$ & 0.02 & 0.02 & 0.06 & $0.11^{\star \star \star}$ & 0.06 & 0.04 & 0.17 \\
\hline & Nitrate (mg L-1) & $4.36^{*}$ & 2.01 & 2.70 & 9.40 & $2.04^{* * *}$ & 0.77 & 1.30 & 3.60 & $2.88^{* x *}$ & 1.24 & 1.10 & 4.70 \\
\hline & Phosphate (mg L-1) & 1.10 & 0.52 & 0.74 & 2.50 & 1.18 & 0.86 & 0.41 & 2.50 & $0.95^{* *}$ & 0.23 & 0.61 & 1.36 \\
\hline & Nitrite (mg L-1) & 0.06 & 0.01 & 0.05 & 0.09 & 0.07 & 0.04 & 0.03 & 0.15 & 0.06 & 0.03 & 0.03 & 0.13 \\
\hline & Nitrate (mg L-1) & 5.31 & 0.44 & 4.70 & 6.20 & 5.32 & 0.77 & 4.50 & 6.70 & 4.96 & 0.32 & 4.30 & 5.30 \\
\hline & Phosphate (mg L-1) & 0.97 & 0.67 & 0.22 & 1.07 & 0.63 & 0.30 & 0.29 & 1.06 & 0.45 & 0.25 & 0.33 & 2.50 \\
\hline
\end{tabular}

Temperature: Temperatures in the surface water were generally high in the dry season with mean values around $30^{\circ} \mathrm{C}$ and an extreme value of $41.3^{\circ} \mathrm{C}$ measured in Andreba (D2), the study site with lowest water levels (Table 1). In the rainy season, the mean temperature of the surface water at site D1 and D3 was significantly lower ( $p \leq 0.001, n=160$ ) than in the dry season with $25.7^{\circ} \mathrm{C}$. No seasonal difference was determined at site D2 with a mean of $29.6{ }^{\circ} \mathrm{C}$ in the rainy season (Figure $3 \mathrm{c}, \mathrm{d}$ ). A significant temperature decline (D1, D2: $p \leq 0.001, n=160$; $D 3: p=0.006$, $n=160$ ) regarding the water depth occurred within all three sites.

Oxygen: The highest concentrations of dissolved oxygen (DO) in the dry season were measured in Anororo (D3) with a mean of 92\% (6.3 mg L-1) implicating supersaturation of oxygen prevailing around midday in Anororo: $43 \%$ of the measurements exhibited DO concentrations higher than $100 \%$ (Figure $3 e, f$ ). Lowest oxygen concentrations during the dry season were measured in Andreba (D2) with a mean of $52 \%$ (3.7 $\left.\mathrm{mg} \mathrm{L}^{-1}\right)$.

Results of the rainy season showed a moderate decrease of DO at D1 and D2 compared to the dry season, while marked seasonal changes occurred in the highly-degraded site D3. Here the DO concentration dropped significantly ( $p \leq 0.001, n=160$ ) from $92 \%\left(6.3 \mathrm{mg} \mathrm{L}^{-1}\right)$ in the dry season to $41 \%\left(3.1 \mathrm{mg} \mathrm{L}^{-1}\right)$ in the rainy season (Figure $3 e, f$ ). The degraded sites D2 and D3 were characterized by exceeding low oxygen concentrations within the mornings in the rainy season. The low-degraded site D2 showed a mean of only $22 \%\left(1.4 \mathrm{mg} \mathrm{L}^{-1}\right)$, the highly-degraded site D3 a mean of $26 \%\left(2.0 \mathrm{mg} \mathrm{L}^{-1}\right)$. Significant differences of oxygen concentrations between the marsh vegetation and the open water were only detected for the low-degraded site D1. Here, DO of the deep water within the vegetation (57\%, $4.3 \mathrm{mg} \mathrm{L}^{-1}$ ) was significantly lower $(p \leq 0.001, n=112)$ than in the open water $\left(72 \%, 5.4 \mathrm{mg} \mathrm{L}^{-1}\right)$.

Luminosity: The highest luminosity within the surface water in the dry season was measured at D3 with a mean of 1,826 lux (Table 1). The lowest mean value was measured at D2 with 326 lux. A brown coloration of the water during the dry season (lower water levels) was observed more frequently, which was likely related to sediments stirred up by fishes. During the rainy season, a significant decrease of luminosity was observed for all sites with lowest light penetration of 149 lux within the water column in D2 ( $p \leq 0.001, n=160$ ) and highest luminosity of 1066 lux in D3 ( $p \leq 0.001, n=160$ ). Low light penetration in the rainy season was often accompanied by a black colored, foul smelling water.

Nutrients: The average nitrate content ranged between $2.04 \mathrm{mg} \mathrm{L}^{-1}$ at D2 and $4.36 \mathrm{mg} \mathrm{L}^{-1}$ at D1 during the dry season (Table 2). Nitrate rose up to mean values around $5.31 \mathrm{mg} \mathrm{L}^{-1}$ and was very similar in all three sites during the rainy season (Table 2). 



Figure 3. Box-whisker plots (showing median, upper and lower quartiles, and minimum and maximum values) of the daily range of water level (a, b), temperature (c, d) and dissolved oxygen $(\mathrm{e}, \mathrm{f}$ ) at the Lake Alaotra during the dry (left) and the rainy season (right) within the open water of the three study sites shown. (D1 = Vohimarina, D2 = Andreba, D3 = Anororo. Letters indicate statistical significant differences between dry and rainy season $(n=160)$ analyzed with Mann-Whitney $\mathrm{U}$-Test and corrected by sequential Bonferroni method; significance was determined as $p=\leq 0.05$ )

Phosphate concentrations showed no site specific differences. $\mathrm{PO}_{4}^{3-}$ ranged between $0.95 \mathrm{mg} \mathrm{L}^{-1}$ at D3 and $1.18 \mathrm{mg} \mathrm{L}^{-1}$ at D2 during the dry season. $\mathrm{PO}_{4}{ }^{3-}$ ranged from $0.45 \mathrm{mg} \mathrm{L}^{-1}$ at $\mathrm{D} 3$ to $0.97 \mathrm{mg} \mathrm{L}^{-1}$ at $\mathrm{D} 1$ during the rainy season (Table 2). Nitrite concentrations differed significantly ( $p \leq 0.001, n=20$ ) between the sites in the dry season with values between $0.04 \mathrm{mg} \mathrm{L}^{-1}$ (D2) to $0.13 \mathrm{mg} \mathrm{L}^{-1}$ (D1)

Plant diversity and abundance: A total of 22 plant species were identified within the lake shore vegetation at all three sites. Most of the species are either native or naturalized (reproduce by themselves) (Supplementary Material 5). Echinochloa pyramidalis (mean cover $=11.5 \%$ ), Phragmites australis (mean cover $=2.9 \%$ ), the Polygonaceae Persicaria glabra (mean cover $=2.1 \%$ ) and the Onagraceae Ludwigia stolonifera (mean cover $=6.2 \%$ ) were the most abundant species within this group. Two endemic species were identified: Argyreia vahibora (mean cover $=2.2 \%$ ) and Cyperus madagascariensis (mean cover $=0.7 \%$ ). Two invasive species were the most abundant plant species: Eichhornia crassipes appeared with a mean cover of $25 \%$ followed by Salvinia spp. with $15.6 \%$. While the number of species within the genus Salvinia is not yet clarified, it is assumed that at least one invasive species, Salvinia molesta, can be found at the lake.

Site specific plant composition: Eichhornia crassipes and Salvinia spp. were the most abundant plant species within the marsh vegetation bordering the open water. However, there was a high variation in species occurrence and cover between the three sites (Figure 4). The abundance of $E$. crassipes increased with level of degradation: it dominated $53 \%$ of the lake shore vegetation at D3 followed by D2 where it had a cover of $24 \%$. At D1, E. crassipes was nearly absent with a mean cover of $0.4 \%$ and a maximum of $10 \%$ cover which differed significantly to the other sites (D1/D2: $\mathrm{p} \leq 0.001, \mathrm{n}=120$ ).

Salvinia spp. characterized the intermediate-degraded site D2 with a significant higher mean cover compared to D1 and D3 (D1/D2: $p \leq 0.001, n=120 ; D 2 / D 3: p=0.001, n=114$ ). In D1, the native grass Echinochloa pyramidalis was the most abundant plant species with a significant higher cover than in D2 $(p=0.010$, $n=120)$ and D3 ( $p=0.014, n=116)$. Hydrophytes occurred mainly in the most intact site D1: the water lily Nymphaea nouchali covered $8.6 \%$ of the open water. Its abundance was significantly lower in the intermediate-degraded site D2 $(p=0.017, n=120)$ where $N$. nouchali was rare and in the highly-degraded site $D 3(p=0.009$, $\mathrm{n}=116$ ) where it was absent. The Menyanthaceae Nymphoides indica appeared only in D1.
Total cover: In Vohimarina (D1) and Andreba (D2) the mean vegetation cover within the marsh belt accounted for $72 \%$ $(S D=33 \%, n=36)$ and $74 \%(S D=34 \% n=36)$. The rest was represented by open water surface (D1: mean $=26 \%, S D=32 \%, n=36$; D2: mean $=23 \%, S D=31 \%, n=36$ ). In Anororo (D3), the vegetation accounted for only $45 \%$ ( $S D=27 \%, n=36$ ) while the open water surface covered $53 \%(S D=29 \%, n=36)$.

Species abundance in relation to human disturbance: At the low-degraded site D1 the species abundance in transects near to the canal $(\mathrm{CN})$ and transects far from the canal (CF) showed no statistical significant difference. At D2 the Onagraceae Ludwigia stolonifera had a significantly higher abundance in $\mathrm{CN}$ (CN: mean cover $=14.6 \%, S D=19.1 \%$; CF: mean cover $=5.3 \%, S D=10.8 \%$; $\mathrm{p}=0.012, \mathrm{n}=59)$. Although, Eichhornia crassipes exhibited also a

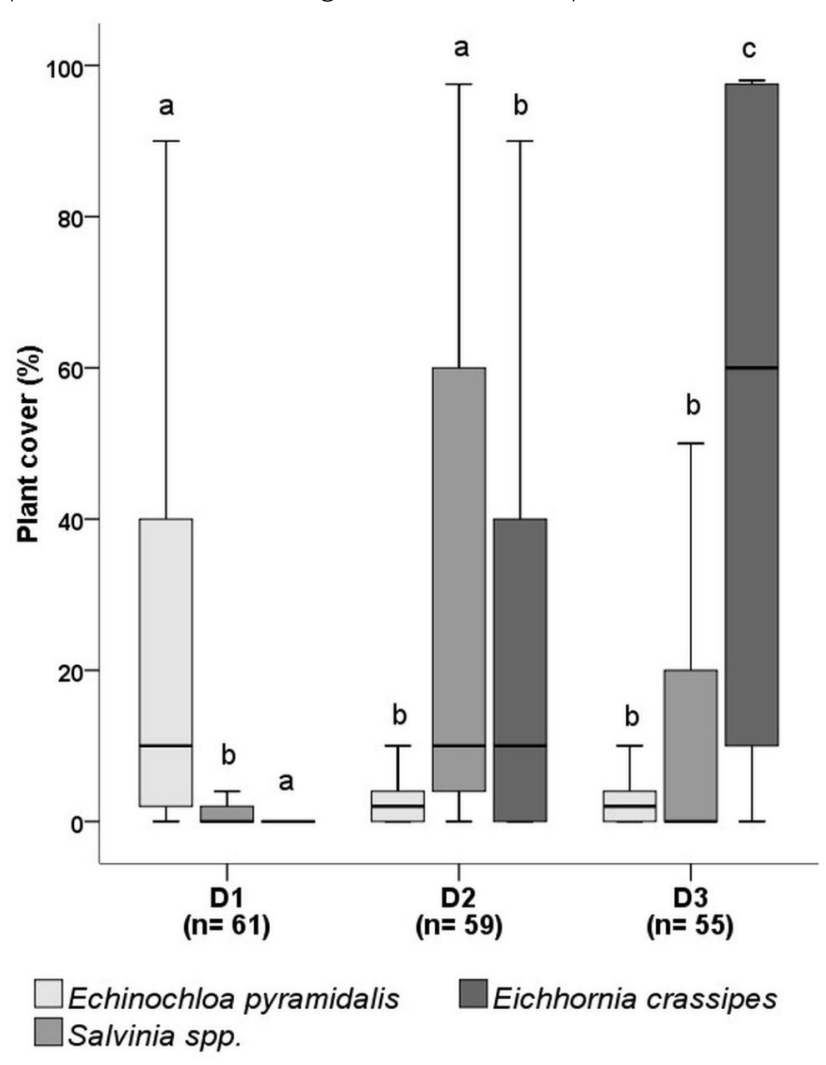

Figure 4. Box-whisker plots (median, upper and lower quartiles and minimum and maximum values) of the three most abundant plant species within the lake shore vegetation of Lake Alaotra. (D1 = Vohimarina, low-degraded; D2 = Andreba, intermediate-degraded; D3 = Anororo, highly-degraded. Differences between sites were analyzed with the Mann-Whitney U-Test using Bonferroni correction. Different letters above columns indicate significant differences; significance was determined at $p=\leq 0.05$ 
higher abundance in CN at D2 the differences were not significant to CF. At D3, E. crassipes and L. stolonifera had a significantly higher cover in $\mathrm{CN}$ whereas Salvinia spp. was significantly less abundant. E. crassipes had a mean cover of $85.4 \%(S D=28.3 \%)$ in $\mathrm{CN}$ and a significantly lower ( $\mathrm{p} \leq 0.001, \mathrm{n}=55$ ) cover of $34.4 \%$ $(\mathrm{SD}=35.3 \%)$ in CF. L. stolonifera occurred with a significantly higher $(p=0.004, n=55)$ mean cover of $12.9 \%(S D=13.4 \%)$ in $C N$ compared to CF (mean cover $=3.5 \%, \mathrm{SD}=7.73 \%$ ). In contrast, Salvinia spp. were significantly less abundant $(p=0.036, n=55)$ in $C N$ (mean cover $=18.8 \%, \mathrm{SD}=4.6 \%$ ) than in $\mathrm{CF}$ (mean cover $=29.0 \%$, $\mathrm{SD}=15.6 \%$.

Vegetation structure: Vegetation structure varied between the three study sites and vegetation density increased with level of degradation. At D3 mean density was $76.5 \%$ at the ground level $(0-3 \mathrm{~cm}$ ) whereas it was only $25.9 \%$ at D1 (Supplementary Material 6). However, regarding the vertical vegetation density profile (Figure $5 a, b$ ) the sites differed especially in the open water. Within the lake shore vegetation (Supplementary Material 7) density declined from $78.3 \%(0-3 \mathrm{~cm})$ to $39.6 \%(50-100 \mathrm{~cm})$ at site D3, $53.5 \%(0-3 \mathrm{~cm})$ to $19.4 \%(50-100 \mathrm{~cm})$ at D2 and from $33.2 \%(0-3$ $\mathrm{cm})$ to $17 \%(50-100 \mathrm{~cm})$ at D1. In the open water (Supplementary Material 8) vegetation density ranged between $73.6 \%(0-3 \mathrm{~cm})$ and $5.0 \%(50-100 \mathrm{~cm})$ at site D3, 48.8\% $(0-3 \mathrm{~cm})$ to $3.4 \%(50-100$ $\mathrm{cm})$ at D2 and $15.3 \%(0-3 \mathrm{~cm})$ to $0.3 \%(50-100 \mathrm{~cm})$ at D1. Regarding the vegetation height, at D1 and D2 vegetation reached a maximum height of 300-500 $\mathrm{cm}$ while the maximum height measured at D3 was only 200-300 cm (Supplementary Material 6). ACcordingly, D3 was characterized by lower but denser vegetation whereas the intermediate- and low-degraded sites showed higher and more open vegetation.

\section{DISCUSSION}

CLASSIFICATION OF LAKE ALAOTRA. Talling and Talling (1965) classified the African lakes based on their conductivity. Lake Alaotra with its low conductivity (50-98 $\mu \mathrm{S}^{-1}$ ) belongs to Class I, characterizing lakes depending largely on rain and run-off or rivers of low salt content (Talling and Talling 1965, Payne 1986, Talling 2009) (e.g., Lake Victoria, Lung'ayia et al. 2001; Lake Tana, Kebede et al. 2006; and Lake Malawi, Chale 2011). Low conductivity is common for lakes fringed by marshes (Howard-Williams and Lenton 1975) like Lake Alaotra, as the vegetation absorbs and accumulate ions when inflow is passing through. Consequently, the overall low conductivity leads to a low buffer capacity (alkalinity) of Lake Alaotra (cf. Talling and Talling 1965). Although highly vulnerable to acidification, Lake Alaotra still has a neutral $\mathrm{pH}(6.8-7.0)$ with partly slight acidic values around 6.0. Pidgeon (1996) descri-
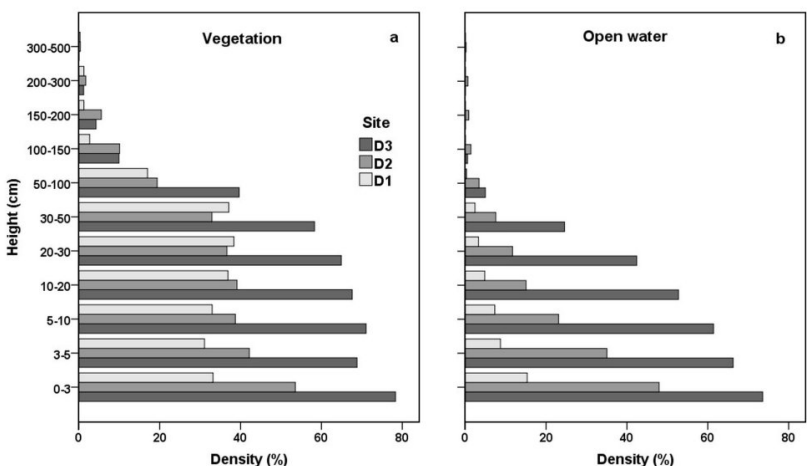

Figure 5 . Vertical vegetation density (mean density in \%) of the plots presenting the lake shore vegetation (a) and the open water (b) of the three study sites. $(\mathrm{D}=$ degradation level; 1 = low, 2 = intermediate, $3=$ high $)$ bed an acidic character of the open lake water (4.3-7.4). Current results are more similar to measured $\mathrm{pH}$ values $(6.8-7.3)$ in the 1970s (Moreau 1980). Studies by Arhonditsis et al. (2003) and Araoye (2009) confirmed the spatial and temporal heterogeneity of $\mathrm{pH}$ in a lake system, which are derived mainly from photosynthetic and respiratory processes as well as nutrient loads (decomposition of organic matter and pollution). Measurements over a restricted time or of a small sample size are therefore highly influenced by daily, seasonal and regional patterns.

WATER LEVEL. Recent studies show that Lake Alaotra has lost ca. $5 \mathrm{~km}^{2}$ of open water surface over the past 30 years (Bakoariniaina et al. 2006). The cumulative effect of multiple factors can further aggravate this situation and eventually lead to the disappearance of the lake, these include: (i) erosion of surrounding hills leading to sedimentation and siltation downhill, (ii) higher evaporation due to vegetation clearance, and (iii) a lower water recharge into the lake due to rainwater percolation in fractures and faults and transformation of water and streams for agricultural irrigation (ibid). Besides a reduction in water surface, a diminution in its water depth as a main driver for the alteration of the abiotic conditions is crucial. Although no specific data is available for the evolution of the depth during the last century, the brownish red coloration of the rivers discharging into Lake Alaotra indicate the lake clearly as a sink for sediments (especially during the rainy season).

WATER TEMPERATURES AND OXYGEN LEVEL. The low water levels of Lake Alaotra imply high water temperatures due to quick heating of the water column. Average temperatures around $30{ }^{\circ} \mathrm{C}$ were reached in the surface water with a maximum of $41.3^{\circ} \mathrm{C}$ measured in Andreba (D2). Other shallow lakes in the tropics show similar high temperatures in the upper water layers. The surface water of Lake George in Uganda for example reached temperatures of $36^{\circ} \mathrm{C}$ (Ganf 1974).

The combination of low water levels and high temperatures can lead to a precarious decrease of dissolved oxygen in the water (Lévêque 1997). During the dry season, the low water column of the Lake Alaotra is heated up rapidly leading to very low solubility of dissolved oxygen $\left(1.2 \%, 0.1 \mathrm{mg} \mathrm{L}^{-1}\right)$. A high oxygen demand from decaying organic material can deplete the level of oxygen as well (ibid). Typically for seasonal flooded wetlands such as the Alaotra wetlands, large amounts of organic matter and nutrients are carried into the lake when the first rains arrive (sensu Payne 1986). Additionally, the lower parts of standing vegetation are subjected to decomposition when water level rises. The considerable drop of the luminosity in the rainy season accounts for the deposition of suspended material in the lake. The marsh vegetation is normally acting like a buffer zone between the lake and surrounding agricultural areas because of its high nutrient uptake (Fisher and Acreman 2004). The high human population at sites D2 and D3 increases the pressure on the marshes. Large parts of the marshes have been converted into agricultural area minimizing their buffer capacity. This is aggravated by an increased nutrient load due to use of fertilizers and pesticides, decaying rice straws after rice harvest and direct wastewater discharges into the lake because of absence or lack of sanitation. Consequently, hypoxic conditions (1.4-2.0 mg L-1) occurred at the more degraded sites during morning periods of the rainy seasons. 
POSSIBLE RESPONSE OF AQUATIC COMMUNITIES TO HYPO$\mathrm{XIA}$. It is assumed that dissolved oxygen is becoming a determining factor for aquatic organisms in the Lake Alaotra. The shallow waters in the littoral zone represent habitat for aquatic invertebrate communities as well as foraging and nursery ground for fish species (Gilinsky 1984, Schramm and Jirka 1989, Petr 2000) and will be particularly affected. However, high water temperatures and low oxygen concentrations in the littoral of Lake Alaotra allow only zooplankton, macroinvertebrate and fish species with morphological, physiological and behavioral adaptations to resist such conditions (Marcus 2001, Ekau et al. 2010, Chang et al. 2013). Lake Alaotra's zooplankton is dominated by the water flea family Daphniidae (Pidgeon 1996). Several studies have proved a high hypoxia resistance of species belonging to the Daphniidae (Larsson and Lampert 2011, Smirnov 2013) while zooplankton abundance and distribution is generally negatively affected (Stalder and Marcus 1997, Qureshi and Rabalais 2001, Roman et al. 2012, Chang et al. 2013). The aquatic macroinvertebrate taxa in Lake Alaotra are represented mainly by molluscs (Limnaea), mosquitoes (Culicidae), dragonflies (Coenagrionidae), mayflies (Baetidae), water-bugs (Heteroptera) and diving beetles (Dytiscidae) (Pidgeon 1996). Although, invertebrates exhibit a wide range of adaptations (Grieshaber et al. 1994, Verberk et al. 2008a, b) depleted oxygen levels can at least contribute to the near absence (Efitre et al. 2011). The fact that hypoxia tolerance is species- and stage-specific and varies widely (Miller et al. 2002) makes it difficult to predict changes in species composition, trophic pathways and productivity without further identification of the macroinvertebrate and zooplankton species of Lake Alaotra.

The ichthyofauna of Lake Alaotra is nowadays dominated by the hypoxia tolerant invasive Tilapia spp. and the snakehead fish Channa maculata (Moreau 1979, Pidgeon 1996, Wallace et al. 2015). Snakeheads are able to uptake atmospheric oxygen (Yu and Woo 1985) while the aquatic breathing Tilapia spp. have hemoglobin with higher affinity to oxygen and can cope with hypoxia up to 2 mg.L-1 (Dusart 1963, Philippart and Ruwet 1982, Verheyen et al. 1985). The native Anguillidae is less tolerant to hypoxia than Tilapia spp. (Hill 1969) and the tolerance range of oxygen concentration of the only left endemic fish species of Lake Alaotra, Rheocles alaotrensis (Batoidae) is not yet documented. In the near future those invasive species may outcompete completely the remaining native and endemic fish species due to their highly adapted metabolism to oxygen poor environments.

INTACT MARSHES VERSUS DEGRADED MARSHES. Regarding

oxygen levels, three site-specific differences can indicate the important role of marshes. (i) Vohimarina exhibited permanent normoxic levels whereas prolonged hypoxia occurred in the perturbed waters of Andreba and Anororo in the rainy season. A lower nutrient discharge into the lake and a higher nutrient uptake by the marsh belt is assumed at the low-degraded site. (ii) The open water of Vohimarina exhibited significant higher oxygen levels in comparison to the marsh belt. The water column of marshes is naturally characterized by lower oxygen concentrations than the open water based on its high primary production resulting in an increased oxygen demand from decomposition processes (Gaudet and Muthuri 1981, Howard-Williams and Thompson 1985, Lévêque 1997). In the degraded sites equalized oxygen conditions within the open water and the marshes might be the result of marsh clearance. (iii) At the highly-degraded site, a wide seasonal range of oxygen concentration has been observed. While hypoxic conditions were frequent in the rainy season, supersaturation arose in the dry season. An intact marsh belt seems to prevent near-shore areas from strong seasonal changes, since it can remove high amount of nutrients passing through at the beginning of the rainy season (Howard-Williams and Gaudet 1985). Related to nutrient discharge, supersaturated as well as hypoxic water could be a sign of eutrophication, which is nowadays widespread in tropical water bodies (Dudgeon et al. 2006).

EUTROPHICATION. Eutrophication of lakes causes rapid growth of phytoplankton and aquatic plants with severe implications for water quality, food web, biotic community structure, biogeochemistry and littoral plant communities (Schindler 2006, Smith et al. 2006, Moss et al. 2011, Søndergaard et al. 2013). Due to the complexity of nutrient dynamics a high frequency of measurements over a long period is still necessary to enable drawing a representative statement about the trophic state of Lake Alaotra. Nevertheless, the current measurements allow to sketch first trends.

Although surrounded by large cultivated areas, the nitrate and nitrite values for Lake Alaotra are comparatively low. Both are far below the guideline values for drinking water with $50 \mathrm{mg}^{-\mathrm{L}^{-1}}$ for nitrate and $3 \mathrm{mg} \mathrm{L}^{-1}$ nitrite (WHO 2011). However, a comparison to nitrate measurements 20 years ago (Pidgeon 1996) manifests a doubling of the nitrate content in the Lake Alaotra.

Generally, low nitrogen contents are common for African lakes (Talling and Talling 1965). Nitrogen often occurs in its reduced form (ammonia) or bound in living plant stocks and sediments (Gaudet and Muthuri 1981, Payne 1986). The overall increase in nitrate during the rainy season can be explained by (i) nutrients (agricultural and natural origin) that were accumulated in the soil and washed out in the rainy season and (ii) large amounts of organic matter that reaches the lake with the first rain.

Elevated phosphate concentrations (1.18 $\left.\mathrm{mg} \mathrm{L}^{-1}\right)$, denote a beginning eutrophication. Samples taken in the 1970s (Moreau 1980) and in the 1990s (Pidgeon 1996) indicated lower concentrations. The origin of the phosphate might be from the release from anoxic sediments (internal loading) of Lake Alaotra and from external sources like pesticides, fertilizer and leaching from the weathered hills. Algae blooms (red or brown algae), observed in calm and shallow waters during the dry season at D2 could be directly related to the higher phosphate concentrations measured at Andreba (D2). Internal loading is accelerated by high water temperatures (Søndergaard et al. 2001) and therefore favorably occurs in quickly heated up shallow waters, during periods of high air temperatures and anoxic conditions.

Enhanced phosphate concentrations, algae blooms, black colored and foul-smelling water and hypoxia are strong signs of eutrophication (Stahl 1979, Lamers et al. 1998, Lamers et al. 2002, Prepas and Charette 2003).

PLANT COMMUNITY CHANGES. In our study a total of 22 plant species were identified, considering the littoral zone of Lake Alaotra. Pidgeon (1996) found a similar number of 23 plant species when he sampled this zone. A comparison of the plant composition points out the changes in species dominance within the fringe area of the marsh belt. Twenty years ago Cyperus madagascariensis and Cyclosorus interruptus were highly abundant within the lake shore vegetation, whereas nowadays they are 
continuously being reduced. Cyperus madagascariensis stands are used by local people for houses and mats (Mutschler 2003, Rendigs et al. 2015) and burned to extend the agricultural areas, pasture or open areas for fishing (Andrianandrasana et al. 2005). Cyclosorus interruptus was mainly observed inside of intact marsh vegetation of Lake Alaotra although it is known to occur in floating fringe areas of the marsh belt exposed to the sun (Hill et al. 1987, Geron et al. 2006). The growing anthropogenic impacts through cultivation, wastewater, biomass harvesting, fire, grazing and fishery is leading to the formation of new plant community types at Lake Alaotra. The most affected zone is the fringe area of the marsh belt due to its easy accessibility. Nowadays, fast growing species like Ludwigia stolonifera, Echinochloa pyramidalis, Eichhornia crassipes and Salvinia spp. characterize the vegetation fringing the water body. Eichhornia crassipes and Salvinia spp. also dominate the open water vegetation while the water lily Nymphaea nouchali, which covered once large parts of the lake before 1950 (Pidgeon 1996), seem to disappear and is only found where human activities are low.

The distribution pattern of the plant species at Lake Alaotra reflect the ongoing changes in species composition and show trends determining plant species abundance and composition in the future: (i) spread of invasive species: Eichhornia crassipes shows highest abundance where disturbance is most developed: in Anororo (D3) where intensive clearance has reduced lake shore vegetation to around $50 \%$ and in canal adjacency (D2 and D3) where nutrient load and mechanical disturbance tends to be highest. (ii) Raise of disturbance-tolerant native species: the native Ludwigia stolonifera, known as a plant with intense vegetative growth and rapid expansion (Sheppard et al. 2006, Lambert et al 2010, Thouvenot et al. 2013), has become one of the prevailing species within the last twenty years (Pidgeon 1996) with a significant higher abundance in areas close to the canal. A study of Njambuya and Triest (2010) at Lake Naivasha (Kenya) has shown the ability of $L$. stolonifera to prosper in the presence of the $E$. crassipes. (iii) Plant species restriction to low disturbed sites: the wide spread of Nymphaea nouchali and Echinochloa pyramidalis exclusively at the low-degraded site (Vohimarina) denotes their sensitivity toward disturbance which is most likely physical damage by boat traffic and the dense mats of Salvinia spp. and $E$. crassipes which may restrict them from light and pressing them physically down

EFFECTS OF THE VEGETATION SHIFT ON AQUATIC AND TERRESTRIAL COMMUNITIES. According to Huston (1979) only species capable of rapid recolonization and growth will persist to increased disturbance levels. Moreover, increased nutrient loads promote the dominance of a few highly competitive species and restrain other species (Pausas and Austin 2001). Changes in plant species composition and abundance during the last two decades and current spatial distribution pattern of plant species at Lake Alaotra highlight trends that will determine the plant community and abundance in the future. The spread of invasive and disturbance-tolerant native species as well as the disappearance of natural species communities occurring still at intact sites will be the main processes in vegetation changes affecting Lake Alaotra on an ecological and economic level (cf. Rakotoarisoa et al. 2015).

Eichhornia crassipes and Salvinia molesta have worldwide altered biodiversity, ecosystem functioning and services in wetlands (Mailu 2001, Calvert 2002, Charles and Dukes 2007). Many African lakes are nowadays invaded by invasive species (Ogutu-Ohwayo et al. 1997, Mailu 2001). Direct effects of the E. crassipes are modification of water clarity, monopolization of light, increased sedimentation, higher evapotranspiration rates, decrease of dissolved oxygen, nitrogen, phosphorous, heavy metals and other contaminants, changes in key habitat structure and waterway clogging (Toft et al. 2003, Jafari 2010, Villamagna and Murphy 2010, Katagira et al. 2011). Particularly the high evapotranspiration rates and sedimentation by the rotting mats (Sambasiva Rao 1988, Villamagna and Murphy 2010) pose a problem for Lake Alaotra due to its shallowness. Sediment deposits due to decomposition of dead plant material of floating E. crassipes mats will most likely play a minor role for the water depth and siltation of the lake as the sedimentation from the eroded hills has a strong impact on the lake.

The effects of Eichhornia crassipes on other aquatic communities are disparate: the abundance and diversity of epiphytic zooplankton and aquatic invertebrates are supported by the structural complexity of the E. crassipes roots and the increased habitat heterogeneity while the decreased food availability (phytoplankton) restricts their occurrence (Villamagna and Murphy 2010). At Lake Naivasha (Kenya) E. crassipes provides refuge for many invertebrates (Adams et al. 2002). Similarly, Pidgeon (1996) found higher species diversity in E. crassipes mats compared to aquatic grassland at Lake Alaotra. Thus, Pidgeon (1996) assumed that invertebrate abundance in the lake does not depend on diversity but density of aquatic plants.

Fish might benefit from a high abundance of epiphytic invertebrates, breeding grounds provided by E. crassipes and reduced predation risk (Mailu 2001, Villamagna and Murphy 2010) as it was the case in Lake Victoria in the 1990s (Mailu 2001, Njiru et al. 2002). However, the low phytoplankton biomass and oxygen concentration under the dense mats can affect negatively planktivorous fish and hypoxia sensitive species (Villamagna and Murphy 2010). Gichuki et al. (2012) documented the alteration of fish communities at Lake Victoria by E. crassipes promoting anoxia tolerant species. Hence, hypoxia-tolerant species of Lake Alaotra could benefit from the oxygen poor conditions under $E$. crassipes mats.

The terrestrial fauna might be affected by the higher density of $E$. crassipes modifying the habitat structure and heterogeneity. Harper et al. (2002) noted that foraging for the fish eagle is impeded by the E. crassipes mats covering Lake Naivasha (Kenya). Villamagna et al. (2012) suspected that changes in the seasonal waterbird community on Lake Chapala (Mexico) were related to $E$. crassipes cover. In Anororo the monospecific and dense E. crassipes mats have already caused wide changes in vegetation structure that can have a considerable bearing on the Lake Alaotra waterfowl and other terrestrial communities. Whether E. crassipes negative or positive influence prevails seems to depend on the size of the mats formed by E. crassipes, original communities and geographic distribution (Bailey and Litterick 1993, Villamagna and Murphy 2010, Chowdhary and Sharma 2013).

\section{CONCLUSION}

The results of this study demonstrate the continuously growing anthropogenic pressure on the Alaotra wetlands altering both water body and vegetation. Our major conclusions are that: (i) Low water levels in the dry season raising the water temperatures and favoring hypoxic conditions. (ii) A disturbed buffer function of the marshes results in depleted oxygen concentrations. (iii) A low buffer capacity makes the lake vulnerable to acidification. (iv) Signs of 
eutrophication such as foul smelling water, algae blooms and increased phosphate concentrations call for further long-term investigations of the trophic state of Lake Alaotra. (v) Anthropogenic activities on the lake and the surrounding marshes promote invasive plant species and disturbance tolerant species and repress native species. (vi) The encroachment of invasive species is highly correlated with human population density.

With a growing human population, resulting in increased demand for fish and agricultural products, the Alaotra wetlands will undergo further pressures. However, it is unclear how much more the lake can buffer in terms of water quality and vegetation alteration. If erosion, sedimentation, marsh clearance and nutrient load proceed unchecked, the cumulative effects may lead to an entire collapse of the Alaotra wetlands.

This article provides an insight in the current ecological state of Lake Alaotra. In consideration of the given facts about the demographic trends it is crucial to close gaps in knowledge about the ecological processes and functions of the lake to enable targeted management strategies and interventions. Further research should therefore (i) focus on the influence of the Alaotra marshes on the dissolved oxygen content in the water to estimate the minimum marsh belt width, which can guarantee its intact buffer function. For this purpose, the nutrient uptake and retention as well as the oxygen gradient from the fringe to the inner marshes has to be analyzed. (ii) To give a better understanding of nutrient sources and cycles, and the eutrophic state of Lake Alaotra, additional parameters like ammonia, total nitrogen and phosphorus as well as chlorophyll-a concentrations, lake turbidity using a Secchi disk and the biological oxygen demand are highly needed. Moreover, an investigation of the exchange processes between the sediment and the open water column and their role in nutrient cycling would clearly lead to a better understanding of the ongoing chemical processes within Lake Alaotra. (iii) As the Lake Alaotra plant community composition and structure undergoes notable changes and the knowledge about the flora of the lake is incomplete and outdated, a plant inventory is needed to identify the occurring species and to know about their abundance. (iv) Further, studies regarding the disturbance tolerance of the plant species of Lake Alaotra can help to understand the alteration of the local plant community composition.

\section{ACKNOWLEDGEMENTS}

We would like to thank our field assistants Bernard Aimé Rajaonarivelo and Lala Nomenjanahary Elysé, the local community of Andreba, Vohimarina and Anororo for their hospitality, the University of Antananarivo, the Durrell Wildlife Conservation Trust Antananarivo and Ambatondrazaka and the Madagascar Wildlife Conservation for their collaboration and finally the "Stifterverband für die Deutsche Wissenschaft" for the financial support.

\section{REFERENCES}

Abdi, H. 2010. Holm's sequential Bonferroni procedure. In: Encyclopedia of Research Design. N. J. Salkind (ed.), pp 1-8. Sage Publication, Thousand Oaks, California.

Adams, C. S., Boar, R. R., Hubble, D. S., Gikungu, M., Harper, D. M. et al. 2002. The dynamics and ecology of exotic tropical species in floating plant mats: Lake Naivasha, Kenya. Developments in Hydrobiology 168: 115-122. (doi:10.1007/978-94-017-2031-1_11)

Andrianandrasana, H. T., Randriamahefasoa, J., Durbin, J., Lewis, R. E. and Ratsimbazafy, J. H. 2005. Participatory ecological monitoring of the Alaotra wetlands in Madagascar. Biodiversity Conservation 14, 11: 2757-2774. (doi:10.1007/s10531-005-8413-y)
Araoye, P. A. 2009. The seasonal variation of $\mathrm{pH}$ and dissolved oxygen (DO2) concentration in Asa lake llorin, Nigeria. International Journal of Physical Sciences 4, 5: 271-274.

Arhonditsis, G., Brett, M. T. and Frodge, J. 2003. Environmental control and limnological impacts of a large recurrent spring bloom in Lake Washington, USA. Environmental Management 31, 5: 603-618. (doi:10.1007/s00267-002-28914)

Bailey, R. G. and Litterick, M. R. 1993. The macroinvertebrate fauna of water hyacinth fringes in the Sudd swamps (River Nile, southern Sudan). Hydrobiologia 250, 2: 97-103. (doi:10.1007/BF00008231)

Bakoariniaina, L. N., Kusky, T. and Raharimahefa, T. 2006. Disappearing Lake Alaotra: Monitoring catastrophic erosion, waterway silting, and land degradation hazards in Madagascar using Landsat imagery. Journal of African Earth Sciences 44, 2: 241-252. (doi:10.1016/j.jafrearsci.2005.10.013)

Bland, J. M. and Altman, D. G. 1995. Multiple significance tests: the Bonferroni method. British Medical Journal 310: 170. (doi:10.1136/bmj.e509)

Calvert, P. 2002. Water Hyacinth Control and Possible Uses. Technical Brief. International Technology Development Center, United Kingdom.

Chale, F. M. 2011. Preliminary studies on the ecology of Mbasa (Opsaridium microlepis (Gunther)) in Lake Nyasa around the Ruhuhu River. Journal of Ecology and the Natural Environment 3, 2: 58-62.

Chang, K. H., Imai, H., Ayukawa, K., Sugahara, S., Nakano, S. I. and Seike, Y. 2013. Impact of improved bottom hypoxia on zooplankton community in shallow eutrophic lake. Knowledge and Management of Aquatic Ecosystems 408, 3 : 1-8. (doi:10.1051/kmae/2013038)

Chaperon, P., Danloux, J. and Ferry, L. 1993. Fleuves et Rivières de Madagascar. Collection Monographie Hydrologique no.10, ORSTOM, Paris, France.

Charles, H. and Dukes, J. S. 2007. Impacts of invasive species on ecosystem services. In: Biological Invasions, W. Nentwid (ed.), pp 217-237. Springer, Berlin.

Chowdhary, S. and Sharma, K. K. 2013. Eichhornia crassipes as a most preferred habitat for macrobenthic invertebrates. Journal of Pharmaceutical and Scientific Innovation 2, 4: 70-72. (doi:10.7897/2277-4572.02458)

Copsey, J. A., Jones, J. P., Andrianandrasana, H., Rajaonarison, L. H. and Fa, J. E. 2009a. Burning to fish: local explanations for wetland burning in Lac Alaotra, Madagascar. Oryx 43, 3: 403-406. (doi:10.1017/\$0030605309000520)

Copsey, J. A., Rajaonarison, L. H., Randriamihamina, R and Rakotoniaina, L. J. 2009b. Voices from the marsh: Livelihood concerns of fishers and rice cultivators in the Alaotra wetland. Madagascar Conservation \& Development 4, 1: 25-30. (doi:10.4314/mcd.v4i1.44008)

Dudgeon, D., Arthington, A. H., Gessner, M. O., Kawabata, Z. I., Knowler, D. J. et al. 2006. Freshwater biodiversity: importance, threats, status and conservation challenges. Biological Reviews 81, 2: 163-182. (doi:10.1017/S1464793105006950)

Dugan, P. J. 1990. Wetland Conservation: A Review of Current Issues and Required Action. IUCN, Gland, Switzerland.

Durbin, J., Funk, S. M., Hawkins, F., Hills, D. M., Jenkins, P. D. et al. 2010. Investigations into the status of a new taxon of Salanoia (Mammalia: Carnivora: Eupleridae) from the marshes of Lac Alaotra, Madagascar. Systematics and Biodiversity 8, 3: 341-355. (doi:10.1080/14772001003756751)

Dusart, J. 1963. Contribution à l'étude de l'adaptation des Tilapia (Pisces, Cichlidae) à la vie en milieu mal oxygéné. Hydrobiologia 21, 3-4: 328-341. (doi:10.1007/BF01025947)

Efitre, J., Chapman, L. J., and Makanga, B. 2011. The inshore benthic macroinvertebrates of Lake Nabugabo, Uganda: seasonal and spatial patterns. African Zoology 36, 2: 205-216.

Ekau, W., Auel, H., Pörtner, H. O. and Gilbert, D. 2010. Impacts of hypoxia on the structure and processes in the pelagic community (zooplankton, macro-invertebrates and fish), Biogeosciences 7: 1669-1699. (doi:10.5194/bg-71669-2010)

El-Shabrawy, G. M. and Al-Ghanim, K. A. 2012. Aquatic Habitats in Africa. Animal Resources in Africa and Their Biodiversity. Encyclopedia of Life Supporting Systems (EOLSS) UNESCO.

Ferry, L., Mietton, M., Robison, L. and Erismann, J. 2009. Alaotra Lake (Madagascar) - Past, Present and Future. Annals of Geomorphology 53, 3: 299-318. (doi:10.1127/0372-8854/2009/0053-0299) 
Fisher, J and Acreman, M. C. 2004. Wetland nutrient removal: a review of the evidence. Hydrology and Earth System Sciences 8, 4: 673-685. (doi:10.5194/hess-8-673-2004)

Ganf, G. G. 1974. Rates of oxygen uptake by the planktonic community of a shallow equatorial lake (Lake George, Uganda). Oecologia 15, 1: 17-32. (doi:10.1007/BF00345226)

Gaudet, J. J. 1977. Natural drawdown on Lake Naivasha, Kenya, and the formation of papyrus swamps. Aquatic Botany 3: 1-47. (doi:10.1016/0304 3770(77)90002-X)

Gaudet, J. J. and Muthuri, F. M. 1981. Nutrient relationships in shallow water in an African lake, Lake Naivasha. Oecologia 49, 1: 109-118. (doi:10.1007/BF00376907)

Geron, C., Owen, S., Guenther, A., Greenberg, J., Rasmussen, R. et al. 2006. Volatile organic compounds from vegetation in southern Yunnan Province, China: Emission rates and some potential regional implications. Atmospheric Environment 40, 10: 1759-1773. (doi:10.1016/j.atmosenv.2005.11.022)

Gichuki, J., Omondi, R., Boera, P., Okorut, T., Matano, A. S. et al. 2012. Water Hyacinth Eichhornia crassipes (Mart.) Solms-Laubach dynamics and succession in the Nyanza Gulf of Lake Victoria (East Africa): Implications for Water Quality and Biodiversity Conservation. The Scientific World Journal 2012: \#106429. (doi:10.1100/2012/106429)

Gilinsky, E. 1984. The role of fish predation and spatial heterogeneity in determining benthic community structure. Ecology 65: 455-468. (doi:10.2307/1941408)

Grieshaber, M. K., Hardewig, I., Kreutzer, U. and Pörtner, H. O. 1994. Physiological and metabolic responses to hypoxia in invertebrates. Reviews of Physiology, Biochemistry and Pharmacology 125: 43-147. (doi:10013/epic.11652)

Guillera-Arroita, G., Lahoz-Monfort, J. J., Milner-Gulland, E. J. and Young, R. P. 2010. Monitoring and conservation of the critically endangered Alaotran gentle lemur Hapalemur alaotrensis. Madagascar Conservation \& Development 5 : 103-109. (doi:10.4314/mcd.v5i2.63140)

Harper, D. M., Harper, M. M., Virani, M. A., Smart, A., Childress, R. B. et al. 2002. Population fluctuations and their causes in the African Fish Eagle (Haliaeetus vocifer (Daudin)) at Lake Naivasha, Kenya. Hydrobiologia 488: 171-180. (doi:10.1023/A:1023390800872)

Hawkins, A. F. A., Andriamasimanana, R., Seing, S. T. and Rabeony, Z. 2000. The sad story of the Alaotra Little Grebe Tachybaptus rufolavatus. Bulletin of the African Bird Club 7, 2: 115-117.

Hill, L. G. 1969. Reactions of the American eel to dissolved oxygen tensions. Texas Journal of Science 20, 4: 305-313.

Hill, R., Webb, G. J. and Smith, A. M. 1987. Floating vegetation mats on a floodplain billabong in the Northern Territory of Australia. Hydrobiologia 150, 2 : 153-164. (doi:10.1007/BF00006663)

Howard-Williams, C. 1975. Vegetation changes in a shallow African lake: Response of the vegetation to a recent dry period. Hydrobiologia 47, 3-4: 381-398. (doi:10.1007/BF00039584)

Howard-Williams, C. and Gaudet, J. J. 1985. The structure and functioning of African swamps. In: The ecology and management of African wetland vegetation. Denny, P. (ed.), pp 153-175. Springer, Netherlands.

Howard-Williams, C. and Lenton, G. 1975. The role of the littoral zone in the functioning of a shallow tropical lake ecosystem. Freshwater Biology 5, 5: 445-459. (doi:10.1111/j.1365-2427.1975.tb00147.x)

Howard-Williams, C. and Thompson, K. 1985. The conservation and management of African wetlands. In: The ecology and management of African wetland vegetation. P. Denny (ed.), pp 203-230. Springer, Netherlands.

Huston, M. 1979. A general hypotheses of species diversity. American Naturalist 113, 1: 81-101.

INSTAT. 2013. Population et démographie de Madagascar. Institut National de la Statistique. <http://www.instat.mg> accessed 26 January 2014

Jafari, N. 2010. Ecological and socio-economic utilization of water hyacinth (Eichhornia crassipes Mart Solms). Journal of Applied Sciences and Environmental Management 14, 2: 43-49. (doi:10.4314/jasem.v14i2.57834)

Junk, W. J. 2002. Long-term environmental trends and the future of tropical wetlands. Environmental Conservation 29, 4: 414-435.

(doi:10.1017/S03768922902000310)
Katagira, F. Kyamanywa, S., Tenywa, J. S., Rajabu, C. A., Sombe, D. and Ndunguru, J. 2011. Impact of interspecific competition by compatriot aquatic weeds on water hyacinth Eichhornia crassipes (Martius) Solms growth and development in the Kagera River. International Journal of Biodiversity and Conservation 3, 8: 345-357.

Kebede, S., Travi, Y., Alemayehu, T. and Marc, V. 2006. Water balance of Lake Tana and its sensitivity to fluctuations in rainfall, Blue Nile basin, Ethiopia. Journal of Hydrology 316, 1-4: 233-247. (doi:10.1016/j.jhydrol.2005.05.011)

Kusky, T. M., Toraman, E., Raharimahefa, T. and Rasoazanamparany, C. 2010. Active tectonics of the Alaotra-Ankay Graben System, Madagascar: Possible extension of Somalian-African diffusive plate boundary? Gondwana Research 18, 2: 274-294. (doi:10.1016/j.gr.2010.02.003)

Lambert, E., Dutartre, A., Coudreuse, J. and Haury, J. 2010. Relationships between the biomass production of invasive Ludwigia species and physical properties of habitats in France. Hydrobiologia 656, 1: 173-186. (doi:10.1007/s10750-010-0440-3)

Lamers, L. P. M., Tomassen, H. B. M. and Roelofs, J. G. M. 1998. Sulfate induced eutrophication and phytotoxicity in freshwater wetlands. Environmental Science and Technology 32, 2: 199-205. (doi:10.1021/es970362f)

Lamers, L. P. M., Falla, S. J., Samborska, E. M., Van Dulken, I. A. R., Van Hengstum, G. and Roelofs, J. G. M. 2002. Factors controlling the extent of eutrophication and toxicity in sulfate-polluted freshwater wetlands. Limnology and Oceanography 47, 2: 585-593. (doi:10.4319/|0.2002.47.2.05)

Larsson, P. and Lampert, W. 2011. Experimental evidence of a low-oxygen refuge for large zooplankton. Limnology and Oceanography 56, 5: 1682-1688. (doi:10.4319/lo.2011.56.5.1682)

Lévêque, C. 1997. Biodiversity Dynamics and Conservation: The Freshwater Fish of Tropical Africa. Cambridge University Press, Cambridge.

Londo, G. 1976. The decimal scale for releves of permanent quadrats. Vegetatio 33, 1: 61-64. (doi:10.1007/BF00055300)

Lung'Ayia, H., Sitoki, L. and Kenyanya, M. 2001. The nutrient enrichment of Lake Victoria (Kenyan waters). Hydrobiologia 458, 1-3: 75-82. (doi:10.1023/A:1013128027773)

Mailu, A. M. 2001. Preliminary assessment of the social, economic and environmental impacts of water hyacinth in the Lake Victoria Basin and the status of control. In: Biological and Integrated Control of Water Hyacinth Eichhornia crassipes, pp 130-139. ACIAR Proceedings N. 102, Australia.

Mangas-Ramirez, E. and Elias-Gutierrez, M. 2004. Effect of mechanical removal of water hyacinth (Eichhornia crassipes) on the water quality and biological communities in a Mexican reservoir. Journal of Aquatic Health and Management 7, 1: 161-168. (doi:10.1080/14634980490281597)

Marcus, N. H. 2001. Zooplankton: responses to and consequences of hypoxia. In: Coastal and Estuarine Studies: Coastal Hypoxia, Consequences for Living Resources and Ecosystems. N. N. Rabalais and R. E. Turner (eds.), pp 49-60. American Geophysical Union, Washington, DC. (doi:10.1029/CE058p0049)

Masifwa, W. F., Twongo, T. and Denny, P. 2001. The impact of water hyacinth, Eichhornia crassipes (Mart) Solms on the abundance and diversity of aquatic macroinvertebrates along the shores of northern Lake Victoria, Uganda. Hydrobiologia 452, 1-3: 79-88. (doi:10.1023/A:1011923926911)

Miller, D., Poucher, S. and Coiro, L. 2002. Determination of lethal dissolved oxygen levels for selected marine and estuarine fishes, crustaceans, and a bivalve. Marine Biology 140, 2: 287-296. (doi:10.1007/s002270100702)

Mitsch, W. J. and Gosselink, J. G. 2000. The value of wetlands: importance of scale and landscape setting. Ecological Economics 35, 1: 25-33. (doi :10.1016/S0921-8009(00)00165-8)

Moreau, J. 1979. Le lac Alaotra à Madagascar: cinquante ans d'aménagement des pêches. Cahiers ORSTOM. Série Hydrobiologie. ORSTOM, Paris.

Moreau, J. 1980. Essai d'application au lac Alaotra (Madagascar) d'un modèle d'étude de pêcheries pour les plaines d'inondation intertropicales. Cahier ORSTOM. Hydrobiologie 13, 1-2: 83-91.

Moss, B., Kosten, S., Meerhof, M., Battarbee, R., Jeppesen, E. et al. 2011. Allied attack: climate change and eutrophication. Inland Waters 1, 2: 101-105.

Mutschler, T. 2003. Lac Alaotra. In: The Natural History of Madagascar. S. M. Goodman and J. P. Benstead (eds.), pp 1530-1534. The University of Chicago press, Chicago. 
Mutschler, T. and Feistner, A. T. C. 1995. Conservation status and distribution of the Alaotran gentle lemur Hapalemur griseus alaotrensis. Oryx 29, 4: 267-274. (doi:10.1017/S0030605300021268)

Mutschler, T., Feistner, A. T. C. and Nievergelt, C. M. 1998. Preliminary field data on group size, diet and activity in the Alaotran gentle Lemur Hapalemur griseus alaotrensis. Folia Primatologica 69, 5: 325-330. (doi:10.1159/000021647)

Njambuya, J. and Triest, L. 2010. Comparative performance of invasive alien Eichhornia crassipes and native Ludwigia stolonifera under non limiting nutrient conditions in Lake Naivasha, Kenya. Hydrobiologia 656: 221-231. (doi:10.1007/s10750-010-0430-5)

Nievergelt, C. M., Mutschler, T., Feistner, A. T. C. and Woodruff, D. S. 2002. Social system of the Alaotran gentle lemur (Hapalemur griseus alaotrensis). American Journal of Primatology 57, 4: 157-176. (doi:10.1002/ajp.10046)

Njiru M., Othina, A., Getabu, A., Tweddle, D. and Cowx, I. G. 2002. Is the infestation of Water hyacinth, Eichhornia crassipes a blessing to Lake Victoria? In: Management and Ecology of the Lake Reservoirs Fisheries. I. G. Cowx (ed.), pp 255-63. Oxford Fishing News Books. Blackwell Science, Tokyo.

Ogutu-Ohwayo, R., Hecky, R. E., Cohen, A. S. and Kaufman, L. 1997. Human impacts on the African great lakes. Environmental Biology of Fishes 50, 2: 117-131. (doi:10.1023/A:1007320932349)

Pausas, J. G. and Austin, M. P. 2001. Patterns of plant species richness in relation to different environments: An appraisal. Journal of Vegetation Science 12, 2 : 153-166. (doi:10.2307/3236601)

Payne, A. I. 1986. The Ecology of Tropical Lakes and Rivers. Wiley, Chichester, U.K. Peck, D. 2004. Madagascar designates its third Ramsar Site. Lemur News 9: 3.

Petr, T. 2000. Interactions between Fish and Aquatic Macrophytes in Inland Waters A review. FAO Fisheries, Technical Paper 396, Rome.

Philippart, J. C. and Ruwet, J. C. 1982. Ecology and distribution of tilapias. In: ICLARM Conference Proceedings. R. S. V. Pullin and R. H. Lowe-Mc Connell (eds.), pp 15-59. Manila.

Pidgeon, M. 1996. An ecological survey of Lake Alaotra and selected wetlands of central and eastern Madagascar in analyzing the demise of Madagascar pochard Aythya innotata. WWF/Missouri Botanical Garden, St. Louis.

Plan Régional de Développement. 2005. Région Alaotra-Mangoro, Province Autonome de Toamasina. Unpubl. Report.

Prepas, E. E. and Charette, T. 2003. Water Bodies: Causes, Concerns, Controls. In: Treatise on Geochemistry. H. D. Holland, K. K. Turekian, (eds.), pp 311-331. Elsevier. (doi:10.1016/BO-08-043751-6/09169-6)

Qureshi, N. A. and Rabalais, N. N. 2001. Distribution of zooplankton on a seasonalIy hypoxic continental shelf. In: Coastal and Estuarine Studies: Coastal Hypoxia, Consequences for Living Resources and Ecosystems. N. N. Rabalais and R. E. Turner (eds.), pp 61-76. American Geophysical Union, Washington, DC. (doi:10.1029/CE058p0061)

Rakotoarisoa, T. F., Waeber, P. O., Richter, T. and Mantilla-Contreras, J. 2015. Water hyacinth (Eichhornia crassipes), any opportunities for the Alaotra wetlands and livelihoods? Madagascar Conservation \& Development. 10, S3: 128-136. (doi:10.4314/mcd.v10i3s.5)

Ralainasolo, F. B. 2004. Action des effets anthropiques sur la dynamique de la population de Hapalemur griseus alaotrensis ou Bandro dans son habitat naturel. Lemur News 9: 32-35.

Ralainasolo, F. B., Waeber, P. O., Ratsimbazafy, J., Durbin, J. and Lewis, R. 2006. The Alaotra gentle lemur. Population estimation and subsequent implications. Madagascar Conservation \& Development 1, 1: 9-10 (doi:10.4314/mcd.v1i1.44044)

Ramsar. 2007. Signatories and Sites <http://www.ramsar.org> accessed 15 January 2014.

Ranarijaona, H. L. T. 2007. Concept de modèle écologique pour la zone humide Alaotra. Madagascar Conservation \& Development 2, 1: 25-42. (doi:10.4314/mcd.v2i1.44128)

Ratsimbazafy, J. H., Ralainasolo, F. B., Rendigs, A., Mantilla-Contreras, J., Andrianandrasana, H. et al. 2013. Gone in a puff of smoke? Hapalemur alaotrensis at great risk of extinction. Lemur News 17: 14-18.

Reinthal, P. N. and Stiassny, M. L. J. 1991. The freshwater fishes of Madagascar: a study of an endangered fauna with recommendations for a conservation strategy. Conservation Biology 5, 2: 231-243. (doi:10.1111/j.15231739.1991.tb00128)
Rendigs, A., Reibelt, L. M., Ralainasolo, F. B., Ratsimbazafy, J. H.and Waeber, P. O. 2015. Ten years into the marshes - Hapalemur alaotrensis conservation, one step forward and two steps back? Madagascar Conservation \& Development 10, S1: 13-20. (doi:10.4314/mcd.v10i1.s3)

René de Roland, L. A., Thorstrom, R., Razafimanjato, G., Rakontondratsima, M. P. H. and The Seing Sam. 2009. Surveys, distribution and current status of the Madagascar Harrier Circus macrosceles in Madagascar. Bird Conservation International 19, 4: 309-322. (doi:10.1017/S095927090900817X)

Roggeri, H. 1995. Tropical Freshwater Wetlands: A Guide to Current Knowledge and Sustainable Management. Kluwer Academic Publishers, Dordrecht, Netherlands.

Roman, M. R., Pierson, J. J., Kimmel, D. G., Boicourt, W. C. and Zhang, X. 2012. Impacts of hypoxia on zooplankton spatial distributions in the northern Gulf of Mexico. Estuaries and coasts 35, 5:1261-1269. (doi:10.1007/s12237-012$9531-\mathrm{x})$

Rommens, W., Maes, J., Dekeza, N. and Ingelbrecht, P. 2003. The impact of wate hyacinth (Eichhornia crassipes) in a eutrophic subtropical impoundment (Lake Chivero, Zimbabwe). I. Water Quality. Fundamental and Applied Limnology 158, 3: 373-388. (doi:10.1127/0003-9136/2003/0158-0373)

Sambasiva Rao, A. 1988. Evapotranspiration rates of Eichhornia crassipes (Mart.) Solms, Salvinia molesta ds Mitchell and Nymphaea lotus (L.) Willd. Linn. in a humid tropical climate. Aquatic Botany 30, 3: 215-222. (doi:10.1016/03043770(88)90052-6)

Schindler, D. W. 2006. Recent advances in the understanding and management of eutrophication. Limnology and Oceanography 51, 1: 356-363. (doi:10.4319//0.2006.51.1_part_2.0356)

Schramm, H. L. and Jirka, K. J. 1989. Effects of aquatic macrophytes on benthic macroinvertebrates in two Florida lakes. Journal of Freshwater Ecology 5 : 1-12. (doi:10.1080/02705060.1989.9665208)

Sheppard, A. W., Shaw, R. H., and Sforza, R. 2006. Top 20 environmental weeds for classical biological control in Europe: a review of opportunities, regulations and other barriers to adoption. Weed Research 46, 2: 93-117. (doi:10.1111/j.1365-3180.2006.00497.x)

Smirnov, N. N. 2013. Physiology of the Cladocera. Academic Press. London, UK.

Smith, V. H., Joye, S. B. and Howarth, R. W. 2006. Eutrophication of freshwater and marine ecosystems. Limnology and Oceanography 51, 1: 351-355. (doi:10.4319/|0.2006.51.1_part_2.0351)

Søndergaard, M., Jensen, P. J. and Jeppesen, E. 2001. Retention and internal loading of phosphorus in shallow, eutrophic lakes. The Scientific World Journal 1: 427-442. (doi:10.1100/tsw.2001.72)

Søndergaard, M., Bjerring, R. and Jeppesen, E. 2013. Persistent internal phosphorus loading during summer in shallow eutrophic lakes. Hydrobiologia 710, 1 95-107. (doi:10.1007/s10750-012-1091-3)

Stahl, J. B. 1979. Black water and two peculiar types of stratification in an organically loaded strip-mine lake. Water Research 13, 5: 467-471. (doi:10.1016/0043-1354(79)90040-X)

Stalder, L. C. and Marcus, N. H. 1997. Zooplankton responses to hypoxia: behavioral patterns and survival of three species of calanoid copepods. Marine Biology 127, 4: 599-607. (doi:10.1007/s002270050050)

Talling, J. F. 2001. Environmental controls on the functioning of shallow tropica lakes. Hydrobiologia 458 1-3: 1-8. (doi:10.1023/A:1013121522321)

Talling, J. F. 2009. Electrical conductance - a versatile guide in freshwater science. Freshwater Reviews 2, 1: 65-78. (doi:10.1608/FRJ-2.1.4)

Talling, J. F. and Talling, I. B. 1965. The chemical composition of African lake waters. Internationale Revue der gesamten Hydrobiologie und Hydrographie 50, 3 : 421-463. (doi:10.1002/iroh.19650500307)

Thouvenot, L., Haury, J., and Thiebaut, G. 2013. A success story: water primroses, aquatic plant pests. Aquatic Conservation: Marine and Freshwater Ecosystems 23, 5: 790-803. (doi:10.1002/aqc.2387)

Toft, J. D., Simenstad, C. A., Cordell, J. R. and Grimaldo, L. F. 2003. The effects of introduced water hyacinth on habitat structure, invertebrate assemblages, and fish diets. Estuaries 26, 3: 746-758. (doi:10.1007/BF02711985)

Turner, R. K., Van Den Bergh, J. C., Söderqvist, T., Barendregt, A., van der Straaten, J. et al. 2000. Ecological-economic analysis of wetlands: scientific integration for management and policy. Ecological Economics 35, 1: 7-23. (doi:10.1016/S0921-8009(00)00164-6) 
Van der Valk, A. G. 2012. The biology of freshwater wetlands. Oxford University Press, New York.

Vareschi, E. 1982. The ecology of Lake Nakuru (Kenya). III Abiotic factors and primary production. Oecologia 55, 1: 81-101. (doi:10.1007/BF00386722)

Verberk, W. C. E. P., Siepel, H. and Esselink, H. 2008a. Life-history strategies in freshwater macroinvertebrates. Freshwater Biology 53, 9: 1722-1738. (doi:10.1111/j.1365-2427.2008.02035.x)

Verberk, W. C., Siepel, H. and Esselink, H. 2008b. Applying life-history strategies for freshwater macroinvertebrates to lentic waters. Freshwater Biology 53, 9: 1739-1753. (doi:10.1111/j.1365-2427.2008.02036.x)

Verheyen, E., Blust, R. and Doumen, C. 1985. The oxygen uptake of Sarotherodon niloticuS $L$. and the oxygen binding properties of its blood and hemolysate (Pisces: Cichlidae). Comparative Biochemistry and Physiology Part A: Physiology 81, 2: 423-426. (doi:10.1016/0300-9629(85)90158-6)

Villamagna, A. M., and Murphy, B. R. 2010. Ecological and socio-economic impacts of invasive water hyacinth (Eichhornia crassipes): a review. Freshwater Biology 55, 2: 282-298. (doi:10.1111/j.1365-2427.2009.02294.x)

Villamagna, A. M., Murphy, B. R., and Karpanty, S. M. 2012. Community-level waterbird responses to water hyacinth (Eichhornia crassipes). Invasive Plant Science and Management 5, 3: 353-362. (doi:10.1614/IPSM-D-11-00085.1)

Waeber, P. O. and Hemelrijk, C. K. 2003. Female dominance and social structure in Alaotran gentle lemurs. Behaviour 140, 10: 1235-1246. (doi:10.1163/156853903771980576)

Wallace, A. P. C., Milner-Gulland, E. J., Jones, J. P. G., Bunnefeld, N., Young, R. E. 2015. Quantifying the short-term costs of conservation interventions for fishers at Lake Alaotra, Madagascar. PLOS ONE 10, 6: 1-15. (doi:10.1371/journal.pone.0129440)

WHO 2011. Guidelines for drinking-water quality - 4th ed. World Health Organization Press, Geneva, Switzerland. Available at <http://www.who.int/water_sanitation health/publications/2011/dwq_ guidelines/en>

Wilmé, L. 1994. Status, distribution and conservation of two Madagascar bird species endemic to Lake Alaotra: Delacour's grebe Tachybaptus rufolavatus and Madagascar pochard Aythya innotata. Biological Conservation 69, 1: 15-21. (doi:10.1016/0006-3207(94)90324-7)

Yu, K. L. and Woo, N. Y. S. 1985. Effects of ambient oxygen tension and temperature on the bimodal respiration of an air-breathing teleost, Channa maculata. Physiological Zoology 58, 2: 181-189. (http://www.jstor.org/stable/30158565)

\section{SUPPLEMENTARY MATERIAL.}

\section{AVAILABLE ONLINE ONLY.}

Table S1: Mean, standard deviation (SD) and range (Min., Max.) of the water parameters at the three study sites with different level of degradation.

Table S2: Mean, standard deviation (SD), and range (Min., Max.) of the water parameters measured within the open water at Vohimarina during the four daily periods.

Table S3: Mean, standard deviation (SD), and range (Min., Max.) of the water parameters measured within the open water at Andreba during the four daily periods.

Table S4: Mean, standard deviation (SD), and range (Min., Max.) of the water parameters measured within the open water at Anororo during the four daily periods.

Table S5: Plant species, growth forms, site specific and plant species cover in \%.

Table S6: Shown are means and standard deviation of the vertical vegetation density at the three sites.

Table S7: Shown are means and standard deviation of the vertical vegetation density of the lake shore vegetation at the three sites. Table s8: Shown are means and standard deviation of the vertical vegetation density on the open water at the three sites. 